\title{
At the Intersection of Journalism, Literature, and Blogging: Negotiating Resistance in Riverbend's Baghdad Burning: Girl Blog from Iraq
}

\section{Amany El-Nahhas}

Assistant Professor, Faculty of Arts, Helwan University, Egypt.

\begin{abstract}
The overlapping disciplines of literature and journalism have created what is commonly called 'Literary Journalism' which conjoined with blogging have manifested into a medium of expression that defies the limited boundaries of conventional journalism, traditional literature as well as mainstream news media. Baghdad Burning presents a pseudonymous account of an Iraqi female computer programmer in her twenties who accounts for the gruesome reality of what it means to be under war and occupation. She recounts a passionate, yet true-to-life experiences about intensifying power outages, travel restrictions, massive human rights violations, increasing fundamentalism, political conflicts, eroding gender rights, political turmoils, and persistent sectarian violence.

The first part of the study examines the historical and political context of both narrative journalism and blogging on the local and global scale. The second part investigates Gilles Deleuze and Félix Guattari's philosophy of the 'rhizome', Brian Martin's 'backfire model' and Jerry Jenkins's conception of 'participatory culture' in order to show that in a digital culture, the act of literary journalism, through blogging, is an act of resistance that goes beyond the originally intended goal of the author into uncontrollable, undesigned, and sometimes uncalled for global cultural and political flows that inevitably generate substantial social and political changes. In other words, the paper manifests that despite Riverbend's assertion that her weblog does not promote political change, it does inspire new meanings, connections, and synergies between facts, news, information, statistics, numbers, current events, and professional reporting on the one hand, and thoughts, feelings, ideas, images, colors, lives, knowledge, experiences, symbolism, imagination, storytelling and amateur narratives on the other. As such, the study proceeds from an awareness that the intersection between journalism, blogging, and literature do not just transform contemporary media landscapes but they also garner new awareness that expands the parameters of both mainstream reporting and literature into newer and more progressive horizons.
\end{abstract}

Keywords: Blogging, narrative journalism, New Journalism, Literary Journalism, resistance, rhizome, digital culture. 
The overlapping disciplines of literature and journalism have created what is commonly called 'Literary Journalism' which conjoined with blogging have manifested into a medium of expression that defies the limited boundaries of conventional journalism, traditional literature as well as mainstream news media. Baghdad Burning presents a pseudonymous account of Riverbend, an Iraqi female computer programmer, in her twenties who accounts for the gruesome reality of what it means to be under war and occupation. She recounts a passionate, yet true-to-life experiences about intensifying power outages, travel restrictions, massive human rights violations, increasing fundamentalism, political conflicts, eroding gender rights, political turmoil, and persistent sectarian violence. The first part of the study examines the historical and political context of both narrative journalism and blogging on the local and global scale. The second part investigates Gilles Deleuze and Félix Guattari's philosophy of the 'rhizome', Brian Martin's 'backfire model' and Jerry Jenkins's conception of 'participatory culture' in order to show that in a digital culture, the act of literary journalism, through blogging, is a tool of resistance that goes beyond the originally intended goal of the author into innovative cultural and political flows that inevitably generate substantial social and political interpretations. In other words, the paper manifests that despite Riverbend's assertion that her weblog does not promote political change, it does inspire new meanings, connections, and synergies between facts, news, information, statistics, numbers, current events, and professional reporting on the one hand, and thoughts, feelings, ideas, images, colors, lives, knowledge, experiences, imagination, storytelling and amateur narratives on the other.

Literary Journalism or New Journalism manifested American realist fiction's failure to address the inner and outer workings of a rapidly and constantly changing society in a way that defeats the 'objective' performance claimed by American novelists from the $18^{\text {th }}$ century until the early $20^{\text {th }}$ century (Chamonikolas 3 ). Literary journalism is a form of writing that weaves together journalism and literature to broaden "journalism's literary scope by placing the author at the center of the story, channeling a character's thoughts, using nonstandard punctuation, and exploding traditional narrative forms" (Boynton xii). In addition, Recep Yılmaz et al. define narrative journalism as a "type of journalism [that] focuses on the life and feelings of the people forming the subject of news" (469). Therefore, it was a revolutionary movement that responded to the 1960s radical social and political upheaval that manifested itself not only in the Vietnam War, the Cuban Missile Crisis, and the assassinations of highly influential political figures including Martin Luther King and President John F. Kennedy, but also the beginning of the Freedom Speech Movement, Anti- War protests, Woodstock, the civil rights movements, the second wave-feminism, Freedom Riders, the hippie movement, Stonewall uprising among other series of turbulent events that took people's lives into account and shook the world into new realities that carried over into the 1970s required new tools to address them.

Tom Wolfe is a creative American essayist, an award-winning journalist and a best-selling author who is known for pioneering "New Journalism" which took journalism into a whole new level in the 1960s and 1970s. Wolfe has identified the basic characteristics that shape new journalism. New Journalism employs a full-fledged/comprehensive dialogue, scene-by-scene progression, thorough and true to life examination of the characters minutest details (especially when it comes to status as in Wolfe's case, or to social and psychological depth as in Gay Talese's), a polyphony of characters and points of view that reflect the broad range of life possibilities, rather than solely the rigid boundaries of the author's perspective (Goc 280; Ricketson 19). 
While Wolfe was totally focused on status, other writers took new journalism to newer horizons. Truman Capote is one of the leading voices of New Journalism. His non-fiction novel In Cold Blood is a journalistic masterpiece that presents not just the heinous quadruple murder of a mid-Western American family, but also a rigorous analysis and a socially insightful commentary on American violence. Gay Talese is another pioneering figure of New Journalism who challenged orthodox reporting styles by introducing storytelling and literary techniques into traditional news reporting and journalism. His attention to detail and passion for the experiences and output of ordinary people were clearly manifested in his intense and unfailing curiosity not just in the lives of Muhammad Ali and Frank Sinatra but also in those of criminals, nudists, swingers and even voyeurs. Another central figure in New Journalism is Hunter Thompson who introduced a style of new journalism called "gonzo journalism." Gonzo journalism, while also blending journalism and fiction, is all about breaking through the conventional restrictions of not just "what" the journalist wrote, but also "how he wrote it" (Stephenson 17). Defying the commandments of journalistic language, style, and objectivity challenged the power of both journalism and the state (Stephenson 17) creating a nonfiction journalism that can be described as subjective, political, people-oriented yet engaging, verifiable, and truthful.

Thirty years later, new journalism has broadened in scope to expand into what has been widely dubbed as "New New Journalism" or what Robert Boynton celebrates as "the most popular and influential development in the history of American literary non-fiction" (xi). Addressing pressing issues of race and class and shifting the spotlight from people of status to real people with real stories marked the core of what New New Journalism has been concerned about. New New Journalists "view the disenfranchised not as exotic tribes, but as people whose problems are symptomatic of the dilemmas that vex America" (Boynton xiv-xv).

\section{From Journalism and (Digital) Technology into Blogging and resistance}

John V Pavlik and Frank Bridges perceive the interrelationship between media and technology to be 'transformative' in the way news is generated and disseminated, the type of information and experiences communicated, as well as the way they are received by readers and viewers alike (qtd. in Yilmaz et al. 455). Journalism, in general, and new new journalism, in particular, was directly affected by the rapidly changing news and media landscape as a result of a growing revolution in information technology that signaled a major shift from the powerful grip of traditional journalism into the threatening hands of web-based news. Technology has served to bring about a corpus genre of journalism that move beyond the communication of news and information into challenging the dominant culture through supporting and sustaining collective self-directed action-based engagement. This development has been manifested in a collective of journalistic genres that include civic journalism, visual journalism, gonzo journalism, community journalism, watchdog journalism, investigative journalism, and advocacy journalism that were mainly responding to the increasing numbers of digital news readership as a result of the rise and expansion of the internet.

Citizen journalism is a style of reporting that refers to the collection, reportage, analysis, and dissemination of facts, news events, and information by common people via the internet. It is an inexpensive open access public platform for user-generated content that is presented particularly through digital media in order to foster civic engagement in social and political issues. As a participatory type of journalism, citizen journalism has provided ordinary citizens with a viable and interactive tool to express their opinions, voice their views, and shed light on 'their' 
real-life issues from within the safety of their homes chipping away at the widely circulating distracting issues of hegemonic culture. Different forms of citizen media include audio and videosharing web-portals, internet forums, social networks, internet chat groups, mobile social networking applications as well as personal and public blogs.

Milblogs manifest the significant influence of these technological forces on new media in the internet era. Though the earliest and most common form of blogs began in the late 1990s as personal online journalistic entries in which authors shared their stories, experiences, thoughts, and perceptions of their surroundings, milblogs had a positive edge over personal blogs. Politically correct and commercially motivated journalism was replaced by online diaries that attempted to tell true-to-heart military-based accounts of war, life, and death as experienced by veterans, soldiers, former military personnel, or military spouses whose lives have been deeply affected by the war. Milblogs first came out in 2003 in response to Iraq War. Colby buzzell's ${ }^{1}$ My War: Killing Time in Iraq, Jason Hartley's Just Another Soldier (2001), and C.J. Grisham's ${ }^{2}$ A Soldier's Perspective (2004) are just some of the examples of war blogs that challenge misinformation about war, misconceptions about America's foreign policy, post-invasion Iraq and modern warfare. Grisham states,

We serve the American people. We are not better than them and we are not worse than them, but we serve them . . I say this because there is a belief out there that people who serve shouldn't criticize those who have. Somehow, by serving, we are supposed to be immune from criticism, especially when the person doing the criticizing never served. This couldn't be further from the truth. We do not serve to protect our own rights; we serve to protect the rights of all Americans and the ability to criticize our government officials is a quintessential and fundamental right.

Milblogs, as such, have taken online journalistic reporting into a whole new level where the main focus lies in drawing attention to America's perpetual years of preemptive strikes, drone warfare, and preventive wars that have resulted in years of unjustified and massive attacks over large populations of foreign peoples in a series of military endeavors that have claimed the lives of both Americans as well as foreign nationals.

Blogs laced with new journalistic techniques have offered the creative and aesthetic space of fiction/literature at the same time that they have helped writers pursue and deliver truth as lived and experienced by their news creators rather than manufactured and directed by media corporations, news rooms, and business beneficiaries. In the same way that literary journalism came out as a response to a time period that was defined by intense and revolutionary changes blogs were part of an evolutionary attempt to address the ongoing onslaught on people's lives and dreams through traditional and institutional media outlets. The blogosphere, as one of different forms of citizen journalism, enabled Iraqis to sidestep traditional journalism with its assumable high-profile reportage to present an alternative journalism that delivers participatory views that are independent of capitalist interests, consumer cultures and hierarchical structures that dominate mainstream media and television networks.

This attempt to out-power and outpace mainstream media has resulted in a surge of Iraqi blogs that have garnered a lot of attention from the international community. Émigré's Iraqi Blog Count was the first non-Iraqi to participate in a sincere attempt at compiling and indexing Iraqi blogs in 2003. Luke Skinners's Olive Branch Optimism presents another unapologetic criticism of a 19-year-old Australian man against his country as well as its other allies' foreign policy. 
Perceiving the attack on Iraq as "the biggest atrocity [his] country has been involved in" (Skinner) manifests what blogs are capable of expressing that would rarely find its way into well-known digital outlets, television networks, or state newspapers. Where is Raed is the first blog to draw attention to Iraqi bloggers. It was written by Salam Pax, the Pseudonym of Salam Abdulmunem, a twenty-nine-year old architect from a well-off family in Iraq. Mosul4all attempts to retain a sense of 'normalcy' through the story of an everyday typical Iraqi man, Choo8i, whose story is recounted through the eyes of an ant. A family in Baghdad is a family blog that is written by two brothers, Raed and Majed Jarrar, and their mother. The blog details a history that goes back to the Ottoman empire and the British occupation. It is a severe, and unrelenting criticism of the Arab world and its people which is as blunt and painful as their criticism of America's foreign policy in Iraq.

In the same way that the extensive number of notes put into a memorandum to the managing editor of Esquire had turned into a launching pad for a vanguard movement that broke the traditions of journalistic writing, reporting, and practice, pushing the boundaries of traditional journalism to create what Tom Wolfe perceives as "that kind of tone that a lot of people are able to reach in writing a letter to a friend" (Bianculli), blogging has created a similar space for freedom and self-expression. A blog has offered a liberating easy-to-use lead generation tool that empowered 'the other' to be written into existence, to come into being, and to materialize visually, verbally, and in writing.

Riverbend's Baghdad Burning has been a serious attempt to socially, historically, politically and economically contextualize the Iraq War and its aftermath. On March 16, 2003, with news on and about the war on Iraq dominating the headlines across the whole world, there was one single truth that took over despite the millions marching in opposition of the war, the humanitarian crisis that the war was destined to bring about on Iraqis whose lives had already been ruined by years of wars and sanctions, and the undeniable illegality of the war (MacAskill and Borger). Despite the overriding opposition of most of the world against the war, the US managed to create a different, strong, though unjustified, reality: Iraq is a real and undeniable threat to the region and to the whole world (Iraq's Weapons of Mass Destruction, Richelson). This 'fabricated reality' was ultimately crowned in the US Secretary of State Colin Powell's notorious speech to the United Nations in a desperate attempt to rationalize the infamous war on Iraq. The overwhelming applause by which Colin Powell's ${ }^{3}$ speech was received on February 5, 2003 was just the tip of the iceberg to the sinister, yet brutal and undeniable, effect that the news media machine can have on the public. The speech that Powell himself later declared 'a great intelligence failure' and 'a blot' on his career (("Avoiding Needless Wars"), Breslow) testifies to the power that ungrounded claims could have over people through brutally politicized media outlets.

Riverbend's blog, as such, was a way to shift attention away from Western media machine's focus on Saddam Hussein or the Iraqi regime's alleged possession of weapons of mass destruction, his possible retention and development of chemical, and biological weapons, including anthrax, its capacity to obtain an atomic bomb, and other traditional hate, fear and warmongering tactics into different unaddressed 'realities.' These realities have to do with people's everyday lives and reinterpreting what war and invasion mean on the ground. Blogging, through new (new) journalism, reinterpreted politically and economically driven terms into emotionally and psychologically charged 'truths' while also highlighting the economic and political toll of war on people's social and emotional wellbeing and behaviors. 
The concept of the rhizome first introduced by Gilles Deleuze and Félix Guattari in $A$ Thousand Plateaus (1987) is crucial here to explain this complex, a-centered, non-hierarchical and non-linear connections that Riverbend draws between different forms of knowledge. Deleuze and Guattari describe a rhizome as a horizontal stem structure that "connects any point to any other point, and its traits are not necessarily linked to traits of the same nature" (21). They contrast the 'rhizomatic' to the 'arborescent.' Whereas the latter refers to a centered, tree-like, ordered and systemic structure that has a clear and distant direction, the 'rhizomatic' is the total opposite. Like the botanical plant stem of ginger, rhubarb, bamboo, strawberry that grow horizontally bearing roots, buds, and shoots, the rhizome creates "random, proliferating and reentered connections" (Colebrook XXVII). In other words, in every single encounter with a different discipline, the outcome is a random and unexpected production that is always in the process of 'becoming' by connecting with another mode of thinking, another science, another form of literature, another type of art, or even a new practice. These connections yield new paths, provoke new meanings, and produce different, multiple, unstable and open-ended possibilities.

The act of tracing the development of new journalism, of drawing connections between journalism and literature is also "rhizomatic" in nature. It is an act of connecting fact and fiction, truth and feelings, reality and storytelling, objectivity and subjectivity which in Deleuze and Guattari's terms produces "active creations, which are in turn capable of further distinctions and articulations" (Colebrook XXVIII).Though Journalism and literature share "a commitment to reporting some kind of truth, the use of languages to convey this truth, and the employment of specific structural and linguistic elements" (Canada 74), both disciplines disagree as to what constitutes "truth". While journalism focuses on telling the truth as it relates to the "material world", literature is motivated more by the inner world of people and their surroundings (3). Truth, in this sense, is not an essential generic beyond time and space factual statement. Richard Rorty confirms that truth doesn't simply exist "out there;" unlike the world. He adds that while "[o]nly descriptions of the world can be true or false. The world on its own - unaided by the describing activities of humans - cannot (5). Truth as such is an open-ended, subjectively perceived, relational, and provisional state of ongoing inquisitive inquiry that can only be attained through the power of 'narrativizing' news stories. Rorty adds that "nothing can serve as a criticism of a final vocabulary save another such vocabulary; there is no answer to a redescription save a re-reredescription" (80).

Blogging, in this way, is a way of going beyond the fallacy of an original picture into connecting with other 'pictures' through 're-re- description' or rather what we may call 're- renarrativization.' This re-re-narrativization is subjectively perceived and emotionally contingent through an emotion which Brian Massumi defines as "a subjective content, the sociolinguistic fixing of the quality of an experience which is from that point onward defined as personal" (28). These emotionally and subjectively-situated re-re-narrativizable vignettes are presented through first person testimonials through which Riverbend takes out and away the emphasis from what 'Americans' want us to focus on, in order to "provide a fuller picture of the human experience" that can only be attained through "emotional involvement" which Thomas Schmidt believes to be the aim of narrative journalism. Replacing September $11^{\text {th }}$ with another more pronounced, strongly ignored and viciously ruthless hundreds of American orchestrated examples of September $11^{\text {th }}$ that have been imposed on Iraqis over 13 years of sanctions and the heinous effects they had on education, health, environment, and the war crimes, death, conflicts, and poverty they brought 
about represents a narrative approach to journalism that presents a relational, subjective account of reality.

These testimonials show that literary journalistic objectivity does not simply rely on verifiable facts, scientific evidence, and statistics, but also subjective feelings. Literary journalism through blogging, as an online expression of personal data entries, has brought together factual data and personal feelings which have become an integral part of the factual experience. Feelings, in this sense, do not oppose objectivity or challenge 'credibility.' Interlaced with literary techniques as well as literary reportage that presents a story in a narrative style of writing places strong emphasis on truth transforms the boundaries between narrative and truth or fact and fiction (Ricketson 161). In her data entry "Setting the Record Straight," Riverbend expresses pure and blatant feelings of "hatred" towards America's military presence in Iraq that are laced with detailed references to specific dates in the history of Iraqis. Riverbend "hates" April 11, April 28, June 3, July 13, among other dates which refer to the death of a friend's family, the merciless loss of a dozen kids and teenagers in Falluja during a peaceful protest, the sense of humiliation felt at checkpoints that have become a constant marker of Iraqi's daily life, and the lengthy time spent at these checkpoints in the midst of extreme weather conditions respectively.

This play of fiction against reality through "emotion" turns into "semantically and symbiotically formed progressions .... narritivizable action-reaction circuits .... function and meaning" which Brian Massumi believes to be both "intensity owned and recognized" (28). Hence, Riverbend's goal goes beyond sharing one's legitimate and justified feelings of anger, loss, and dispossession at the critical path of events in Iraq, into inciting as well as fueling her readers' sense of guilt, outrage, shame, and revulsion through a perpetual and insistent use of questions, redescription (as stated earlier), irony, and repetition that would wake them up to what is happening not only in Iraq but wherever the West interferes. Riverbend attempts to shake the western reader out of his/her utter and unjustified sense of entitlement, supremacy and infallibility, and more importantly complacency, and to spur him/her to seek answers, information and solutions. By combining emotional vignettes, quantitative and qualitative data, hypertextual references, Riverbend wields a political stance that defies the official stance of both Iraqis and Americans. She presents a clear social and political statement on life, society, and the world; hers is a solid, unapologetic, personal stance that is directly integrated into well-written, creative, factual, inquisitive, and narrative journalistic entries. In engaging with the affective productions of literature, the objective productions of journalism, through the electronic medium of blogging, the writer creates a subversive space where disciplines, ideas, concepts, and media expand beyond their prescribed rigid boundaries to illuminate the power dynamics of both interstate and intrastate conflict settings on the one hand, or people's agency and power on the other.

While blogging in itself is an act of resistance as manifested earlier, "digital resistance" as the paper employs refers to the digital techniques that the writer uses within the parameters of blogging to communicate his message. Hypertextuality, for example, is an electronic form of intertextuality that creates interlinked nodes of knowledge. This dialogical transfer between different nodes of knowledge creates not just communication and exposure but also a cognitive, intellectual, and epistemological rhizomatic engagement that Deleuze and Guattari describe as one of "connection and heterogeneity" (7). Hypertextual references have served to enhance as well as expand the intellectual debate on economic and political affairs beyond the constrains of Westernorchestrated discourse. The co-presence of mainstream views in the same digital canvas/page of 
'different'/resistant views creates a site for interactive interrogation and engagement that opens up the way to multiple meanings and interpretations.

Through these digital techniques, Riverbend exposes critical inconsistencies and informational lacuna of both local/state/regional media on the one hand and international media (especially in the US) in their official biased reportage of Iraq before and after war. Riverbend's blog fills in the gap in traditional mainstream media. Her first hypertextual reference takes us directly to BBC's article entitled "Iraq needs tens of billions" published in 2003. Though the article tackles the mounting economic toll of US intervention in Iraq, Riverbend sheds light on one single proclamation by Paul Bremer: "“[Iraq] is not a country in chaos and Baghdad is not a city in chaos." In a series of satiric comments marked by bitterness and disbelief at the "incredulous" statement, Riverbend addresses the devastating social impact of war on women, the increasing assassination attempts targeting political and religious figures, and the rising Shi- Sunni sectarianism unleashing a backlash of inevitable violence and death.

As these convergences between blogging, as an electronic media form, literature, and journalism interact with interlinking (references to other blogs that the blog creator prefers or sees of interest to the reader), they create "transformational multiplicities" (Deleuze and Guattari 11) that are unstructured, undisciplined, and asystemic. Riverbend's writing shows the evolution of blogging into a literary journalistic form that displays how energies that are strong enough to leave what Deleuze and Guattari call "a kind of afterimage" can be "reactivated or injected into other activities, creating a fabric of intensive states between which any number of connecting routes could exist" (IV). Blogging, like writing, becomes a space that defies fixed signifying and, turns more into "surveying, mapping, even realms that are yet to come" (Deleuze and Guattari 5). Blogging reaches across cultural, political, economic, as well as religious, ethnic, and regional divides in order to re-map Iraqi people's life.

Therefore, blogging can be perceived as an electronic medium that "would enable [one] to build [his/her] life and those of the people around [him/her] into a plateau of intensity that would leave afterimages of its dynamism that could be reinjected into still other lives" establishing any form of connections that the writers call "revolution" (XV). As such, Deleuze and Guattari's belief that "There are no points or positions in a rhizome, such as those found in a structure, tree, or root. There are only lines" (8) is clearly manifested in the different turns that Riverbend's blog has taken over the years. First, Baghdad Burning turned from an Iraqi blog into a well-known book that won the International Lettre Ulysses Award for the Art of Reportage in 2005. It was later shortlisted for the Samuel Johnson award, one of the most prestigious, British awards for non-fiction, in 2006, and as such has been a significant contribution to the academic and professional discourse of power on the Iraqi War. The digital-to-print shift of the blog manifests a process of "intermediation" that Theodore G. Striphas uses to point the rhizomatic nature of media, one that is contingent on interrelationship, social and historical dependency, as well as multi-dimensionality and arbitrariness (15-6). These characteristics are further manifested in the later adaptation of Baghdad into a full-length theatrical co-production by Six Figures Theater Company and Barrow Street Productions in 2005. Similarly, the Edinburgh Fringe Festival, the world-leading annual celebration of new theatre, presented another stage adaptation of Baghdad Burning in 2006. Riverbend's blog has been taken also as a major point of departure for the study and critical and scholarly analysis of occupation, gender, blogging, and war in hundreds of courses across the world. Moreover, a BBC Radio 4 magazine program broadcast featured a 15-minute drama 
episodes based on Riverbend's blog, before Information Clearing House turned the blog into 60minute episodes.

Rhizomatic multiple revolutionary lives are demonstrated through the five methods that Brian Martin details as power's tools to appease people's feelings of resentment and anger at constant injustice ("Theory for activists" 29). While Martin details masking injustices, devaluation, reinterpretation of events, and using official mediums to create a sense of justice, in addition to intimidation and bribery as a means of pacifying people's dissent (29), the paper argues that through her literary journalistic blogging, Riverbend manages to twist around these tools of power against their perpetrators through what Martin calls "the backfire model" ("Theory for activists" 29). This inspiring model of resistance has been built on Gene Sharp's notion of "political Jiu-Jitsu" which refers to how the tools used to repress opposition and suppress the masses may end up blowing back against enforcers of injustice (Martin, "Theory for activists" 28). Rather than complex and calculated tools of mitigating the masses and quelling their dissidence, however, Brian Martin's "backfire model" highlights also the tactics of opposition that can be used by the masses to inform, influence and shape the general public opinion that has been largely dominated by economically driven media.

In order to unmask the injustices committed against Iraqis, Riverbend exposes vivid graphic descriptions of explosions, bombings, gunshots, assassinations, violent demonstrations, shattering blasts, sectarian violence, power outages, missile attacks, drone strikes, and other forms of military practices as constant descriptive tags of what Iraqis' post-occupation life has been like. These rigorous details are relentlessly pointed out against the fact that " $[t]$ here was nothing on the news, as usual" or "none of the news channels seem to be covering them" (Riverbend). For example, President Bush's quick visit to Baghdad International airport that was extensively covered to highlight a carefully selected jubilant audience that included Iraqi puppets, who have been directly appointed by the occupation authorities, as well as American troops that were mainly stationed in the relatively safely guarded areas in Baghdad, rather than Falloojeh, Tikrit, Mosul, or Najaf, ignored a more gruesome and highly intense major part of this cautiously crafted picture. On November 29, 2003, Riverbend states,

Bush must be proud today- two more 'insurgents' were shot dead in Ba'aquba: two terrorist sisters, one 12 years old and the other 15 . They were shot by troops while gathering wood from a field... but nobody bothers to cover that. They are only two Iraqi girls in their teens who were brutally killed by occupation troops- so what? Bush's covert two-hour visit to Baghdad International Airport is infinitely more important.

Through this example as well as others, Riverbend exposes more than the biases of news reporting. More importantly, her blog becomes a venue for extending real lived epistemic literacy to readers who claim to belong to a credible and highly objective and independent media culture, but, in fact, have been mostly whitewashed by western media.

Riverbend materializes the voices of the masses whose lives go underreported, undercounted and underestimated in mainstream media. Her literary journalistic blog challenges the idea of "war as infotainment" or what Daya Kishan Thussu defines as "the obsession with high-tech reporting, using a video-game format to present combat operations, with complex graphics and satellite imagery, providing a largely virtual, even bloodless, coverage of war" (2003: 117). Riverbend is not only an Iraqi who accounts for the lives of millions of her people who have lived through wars and sanctions, but she is also a woman in a conservative society whose assumed 
attempt toward liberation has brought about more discrimination and violence. Riverbend's account of the abduction and brutal rape of Sabrine Al-Janabi, the 20-year-old Sunni woman, who was sexually assaulted by three Iraqi security officers is the most brutally blatant example of this attempt to present an alternative to the most commonly propagated, bloodless, sanitized images of war in mainstream media. Combining the visual with the textual through the virtual medium of blogging has managed to present a story of both brutality and resistance that challenges the presumably fair, balanced, or impartial presentation of war through western media platforms that boasts about US/Western engineered liberation, equality, constitutional referendum, major elections, and reconstruction in Iraq at the same time that persistent human rights violations have far outweighed any benefits that the war may have claimed. In presenting Al-Janabi's story, Riverbend integrates three carefully selected pictures of a woman whose eyes and words convey far more than any of the detailed news reportages.

'I told him, 'I don't have anything [I did not do anything].' He said, 'You don't have anything?' One of them threw me on the ground and my head hit the tiles. He did what he did- I mean he raped me. The second one came and raped me. The third one also raped me. [Pause- sobbing] I begged them and cried, and one of them covered my mouth. [Unclear, crying] Another one of them came and said, 'Are you finished? We also want our turn.' So they answered, 'No, an American committee came.' They took me to the judge. (Riverbend)

Riverbend refers to other incidents that are rarely reported in western news: the execution of three Iraqi women (Wassan Talib, Zainab Fadhil and Liqa Omar Muhammad) and the illusion of gender equality that these executions have brought about "Let no one say Iraqi women didn't get at least SOME equality under the American occupation- we are now equally as likely to get executed" (Riverbend)

Riverbend underscores Martin's second tool through which "validat[ing] the target" can only be attained through presenting him/her in a real positive light that highlights his/her humanity (Backfire Manual 11). Riverbend celebrates a human image of Iraqis that serves to not only present positive images of dignity, respect, and beauty, but also to educate her Western readers about their lives. For example, tea drinking is not only a way of sharing a drink, but more importantly an act of socially and mentally bonding over both personal and political affairs. Similarly, details pertaining to Iraqi people's daily religious practices including prayers, widhu (the Islamic ritual washing of different parts of the body before prayers) and their perception of carrying the Quran a means of acquiring "a sense of security" rather than a manifestation of any form of fundamentalism or extremism (Riverbend). Iraq is presented as a rich and vibrant multiethnic and mostly-tribal society where tribalism means more than backwardness or "ignorant land sheikhs or oil princes" Instead, it is a strong social network that gives people a sense of belonging and security that both the occupying forces and the Iraqi army have failed to provide.

Riverbed highlights Iraqis as stubborn survivors. Their survival is more about the insatiable desire to go on and to enjoy even the smallest life details despite their continual day-to-day struggle to secure the basic necessities of their life: water, kerosene, electricity, gasoline, and food. Riverbend states:

The nicest thing about the heaters is the fact that there's always a kettle of water on top of them. This accomplishes two things at once: it keeps the air in the room from getting very dry, and it provides a ready kettle of hot water for the tea ritual during the evening. The 
sopa is also fantastic for heating bread. At night, when there is no hope of electricity, we sit around on the rug, a little distance away from the sopa, and drink sweet tea, with warm bread and some famous Iraqi salted white cheese, while listening to the radio or just talking about family matters, or political matters.

Through these daily life details, Riverbend provides us with what James C. Scott calls "a privileged peek backstage" that lies beneath the "public transcript" displayed by Western official narratives and mainstream journalism. Hiding behind the pseudonym of "Riverbend", the writer manages to provide a relatively safe access not only for her to express her views, but also for readers to have access to what Scott calls the "hidden transcript" of the subordinates. Scott believes that "[every] subordinate group creates .... a hidden transcript that represents a critique of power spoken behind the back of the dominant .... A comparison of the hidden transcript of the weak with that of the powerful and of both hidden transcripts to the public transcript of power relations offers a substantially new way of understanding resistance to domination" (XII) which is what Riverbend presents through her detailed factual account in numbers, statistics, quantitative and qualitative evidence of both sides of the story. Invisibility, in this case, that the pseudonym provides represents a significant asset that enables the writer to critique power while protected behind the fictitious name of Riverbend. It enables her to cross even the boundaries that the powerful may never be able to cross in order to stay politically correct.

Brian Martin's "lying, minimizing, blaming, and framing" which present the core of power's interpretation of events are overturned in Riverbend's blog. Through Martin's third counter tactic of "interpret[ing] the events as unjust," Riverbend has managed to present "counter lies ... counter minimization... counter blaming ... counter framing" (Martin, Backfire Manual 11). At a time when media had control not only over what to be reported, but also how it should be received, when a brutal act of invasion and subsequent occupation that reduced a country to rubble is interpreted as an act of liberation and reconstruction, Riverbend has managed to reinterpret events differently using daily personal log entries that have lasted over years covering from 2003 till 2013. She relies on thorough fact-based historic accounts of pre-war Iraq in order to relate an image of Iraq that opposes Thomas Friedman's claims of partisan divides as well as political and religious rifts where

Religiously, if you want to know how the Sunni Arab world views a Shiite's being elected leader of Iraq, for the first time ever, think about how whites in Alabama would have felt about a black governor's being installed there in 1920. Some Sunnis do not think Shiites are authentic Muslims, and they are indifferent to their brutalization. (Riverbend)

This shows that history, in Deleuzian Rhizomatic terms, presents "the set of preconditions, however recent, that one leaves behind in order to become, that is, to create something new" (Deleuze, Negotiations, 171). A rhizomatic perception of history turns history into a moment of flight, openness, and creation though which newer links may be drawn and newer connections can be recognized. Rather than explaining a religiously-based conflict that is incomprehensible and meaningless to the Western reader, Riverbend provides a contextual framework that is as politically and historically motivated as the conflict between Whites and Blacks. Changing the frame through which the Westerners perceived Middle-Eastern conflicts through comparing the Shi'i-Sunni case with the Black-White one has managed to engender a common ground, a unified consciousness and a robust cross-national emotional solidarity. Against the conscious historical and political deliberation of presenting Iraq as a sectarianism-infested country, Riverbend 
enumerates a list of political Shia officials who had held top government positions (either presidents or prime ministers) in Iraq more than four decades prior to occupation. Among those leading figures are Mohammed Najib Al-Rubayi (1958), Abdul Karim Qassim (1958 - 1963), Naji Talib (1963), in addition to Sadoun Humadi and Mohammed Al-Zubaidi under Saddam Hussein's regime. In other words, while not necessarily a harmoniously homogenous society, Iraq is presented as anything but a country torn by religious divisions. In another example of calculated fabrication of events, Riverbend highlights the brutal politicization of religion that is clearly practiced in the occupying forces' attempt to change Iraqi Personal Status Law into a Shari'a based law that denied Iraqi women most of their previously secured rights to free marriage, divorce, equal pay, education, and ownership, among other rights.

Riverbed uses the 'blaming' technique differently. "Naming for shaming" is a tool that Riverbend employs to expose what she calls the 'puppets' of Iraq. Riverbend's posts are packed with vivid minute details on each and every single Iraqi assumable leader who had been handcrafted by America's foreign policy. The Puppet: Ahmad Al-Chalabi, The Puppet: Iyad Allawi, The Puppet: Jalal Talibani, The Puppet: Abdul Aziz Al-Hakim, among other puppets who represent a group of American-picked, installed, and backed gang of opportunist looters, embezzlers, war profiteers, political hoodlums, and illegal business owners. Framing on the other hand is employed by Riverbend as a means of exposing those assumable leaders for the true criminals they are. Riverbend uses sarcasm as a framing tool of defiance where framing goes beyond its legal meaning of falsely incriminating an innocent person. Sarcasm is meant to undermine and topple down Americans' supremacist beliefs and overall unfounded philanthropic altruistic motives of liberation, stabilization, modernization, and democratization claims. Moreover, it is meant to shake readers (elites, government officials, and the general public alike) into realizing the absurdity of their deeply-held beliefs, challenging the preposterousness of official narratives, and guilting them into coming face to face with a shocking and disturbing fact-check between what they propagate as values and what turns out to be their true reality. Riverbend perceives the whole act of war as an award-winning show, where the nominees are a combination of local and foreign stars who are purely and solely after power and lucrative oil revenues: Hakeem, Al-Jaffari, Hameed, Talabani, Bush, and Rice among other prominent entertainers. Rather than "Oscars," Riverbend devises "Sayid Awards" as a local name that sustains the honorary status of Muqtada Al-Sadr. In her eloquent, compelling sarcastic presentation of the "2006 Sayid Awards", Riverbend frames every single American puppet for their leading role. Moreover, Sayid awards resonate with the "mock awards" perceived as one of the non-violent tactics of resistance (Sharp, How Nonviolent Struggle Works 26). As such, the award-winning show turns into a "mock trial" in which the web-based space of the blog is the courtroom, the readers are the jury, the writer/content producer/blogger is the judge, and the American puppets are the defendants/culprits.

Brian Martin's forth tactic of resistance that pertains to mobilizing support is manifested in Riverbend's blog. Against the economically and politically driven official narratives, blogging (especially political or literary journalist blogging), presents itself as a form of alternative media that generates an online community where it is possible to come together and propose a parallel world that moves away from the monolithic and centralized western media's inter-communal dialogue into a native intra-communal engagement with the West. Blogging creates a sense of oneness across space, race, age, culture, color, sex as well as intellectual, economic, and political gaps. It brings diversity and inclusion of the marginalized voices as characteristics that shape the 
core of what blogging is all about. This is clear in Riverbend's constant references to the Iraqi Agora, Where is Raed, Shlonkom Bakazay?, and Iraqi Spirit as well as her blog sidebar that features links to alternative sources of information including Iraq Occupation Watch, Iraq Body Count, IACenter, Back to Iraq, Dear Raed, Turning Tables, Raed in the Middle, and Today in Iraq. Moreover, Riverbend extends this network of support, information, and shared humanity to include other voices that add not just diversity but also a sense of validation and corroboration. For instance, Riverbend draws attention to Physicians for Human Rights whose real significance lies in their compelling call for action to identify and provide information on minefields and cluster bomb drop sites that would secure the protection of civilians and humanitarian workers. These references are alternative players that challenge hegemonic articulations of war and occupation and provide solid networks of cooperation and solidarity (beyond the boundaries of color, race, and ethnicity). In other words, in Deleuzian terms blogging becomes a stateless, borderless, nomadic, and de-territorialized act of resistance that creates global readership communities and challenges the rigid and hierarchical segmentary divisions of the state apparatus. It is the nomad's "war machine" in Deleuzian terms.

Whereas Brian Martin perceives "intimidation" as the fifth effective tool of suppressing people's resistance or pacifying their outrage, Riverbend uses the same tool against its perpetrators. Riverbend shares fanmail in order to show the other side of the story. She posts the message of one of her readers, Bob Frederick, in order to show the general mindset of Bush's supporters. Bob Frederick's staggering spelling errors which Riverbend describes as "original to the soon-to-beunemployed chimp that wrote them" with no extensive or detailed comment on the blogger's part expresses the space that the reader may have in a digital world. Except for the introductory line and the concluding comment, Riverbend allows the reader's message to speak for itself of the dominant political ideology that reflects the views strongly held and forcefully disseminated through mainstream media outlets. His reference to how 'the more y'all keep tellin' folks on that com-putter thing-a-ma-bob wuts goin' on down there, the more they don't pay no attention to my TV reporter guys on Fox to tell 'em wut they need to know" and the Patriot Act manifests the attachment to mainstream news media outlets and their negative impact on the general public to the point where the latter fails to understand that blogging "the other's opinion" while insisting on Fox, like other politically correct news outlets, shamefully opposes an integral part of the freedom of speech that represents the very basis of the First Amendment of US constitution.

In addition to disseminating grievances, and exposing a different version of 'reality,' new journalism through digital blogging medium has become a site for suggesting solutions to a series of imposed calamities that were mainly brought about by the so-called "coalition of the Willing"'s invasion of Iraq. Riverbend responds to a series of readers' questions concerning what should be done by proposing solutions and inspiring change:

Pull out the American troops. Take them home. Bring in UN peace-keeping troops under the Security Council- not led by America. Let real Iraqis be involved in governing Iraq. Let Iraqis who actually have *families* living in Iraq be involved in governing their country. Let Iraqis who have something to lose govern the country. They aren't being given a chance.

Blogging, as such, enables a free reign through which the writer can speak truth to power, truth that is unimpeded by the calculations of either foreign or state power. 
Considered to be one of the "fastest growing phenomena on the Internet" (Panzner 177) or "the fastest growing electronic medium for writing and distributing opinions and information" (Penrod 1), blogging is part of a newly expanding 'participatory culture' which Henry Jenkins and colleagues describe as "a culture .... in which members believe their contributions matter, and feel some degree of social connection with one another (at the least they care what other people think about what they have created)" (Jenkins et al. 3). This means that blogging creates a creative learning environment that encourages the development and enhances the information and knowledge of both the content producer and the content receiver. Blogging, as one of the affinity spaces identified by Jenkins, provides a 'provisional,' 'ad hoc and localized' informal learning space that paves the way for creativity and freedom from restrictive institutional long-term goals and practices of structured learning (Jenkins et al. 9).

The spontaneity and casualness delivered by informal learning setting also accounts for the unexpected or unplanned results that the content posted may have on the receiver. In a world in which deliberate disinformation is generally generated and circulated to mislead the public opinion for purely political and economic reasons, "the new participatory culture offers many opportunities for youth to engage in civic debates, to participate in community life, to become political leaders, even if sometimes only through the "second lives" offered by massively multiplayer games or online fan communities" (Jenkins et al. 10). This idea is manifested in the participatory response Riverbend has generated among both haters and supporters. While the former resorted to creating a new site riverSbend.blogspot.com, adding only the letter ' $\mathrm{s}$ ' to the blog address, in order to disseminate views that are utterly antithetical to those held by Riverbend, participatory response has not stopped here. Instead, it has broadened to include the reaction of other bloggers who resorted to the vastness of the world wide web in order to backlash against the disinformation of riverSbend.blogspot.com. These include http://suzerainty.blogspot.com and http://www.gorenfeld.net/john/blog.html whose creators have attempted not only to incriminate an act of identity theft, but also to expose a deliberate act of fabrication by "politically-motivated smear merchants" ("Mission Accomplished"). These different acts of participatory response, as such, have generated an interactive atmosphere of rhizomatic learning through which the blurring of the line between readers and content creators holds both of them in a constant and perpetual state of networked learning about both themselves as well as others.

\section{Conclusion}

Employing a balanced mixture of journalism and literature through the blogging medium has simply engendered a rhizomatic world of multiplicities and interrelatedness through which possibilities are endless. In other words, this marked fusion between fact and fiction manifests a rhizomatic process of engagement and activism that defies the hierarchical, linear, uni-centered source and course of activism into a connected, heterogeneous, multi-centered path(s) of dissidence.

Literary journalism in a digital world in which dominant public discourse dictates how people feel, eat, act, love, and live is a way of owning one's narrative. By introducing novelistic techniques into non-fiction, literary journalistic blogging in post-invasion Iraq has been a means for engaging people, both readers and writers alike, into participatory politics of self-world creation that promotes writing and activism. It provides a significant social and political terrain for raising awareness, challenging dominant narratives, and changing perspectives on prevailing forms of ideological and cultural annihilation. 
Moreover, in its digital storytelling/narrative capacity, the blog provides an uncensored free platform for self-expression that presents a digital, emotionally and intellectually stimulating testimony of the truth behind war, imperialism, and mass media. Blogging becomes a citizen channel for news and communication that makes up for the eroding confidence in western media and state-sponsored traditional media discourse. It is a non-traditional form of resistance that manifests civic individual and community engagement both within and beyond cyberspace.

\section{Notes}

${ }^{1}$ Buzzell is the first U.S. soldier serving in Iraq to write a blog detailing his first-hand experiences with war. He is a former US infantry man machine gunner, a critically acclaimed blogger (who is known for his 2003 blog CBFTW which stands for "Colby Buzzell F*ck the War", and an accomplished writer who won the 2007 Lulu Blooker Prize for My War: Killing Time in Iraq.

${ }^{2}$ Grisham is a retired US Army Master Sergeant.

${ }^{3}$ Collin Powell is an American statesperson and the former US Secretary of State from 2001 to 2005. 


\section{Works Cited}

“Avoiding Needless Wars, Part 9: Iraq." Federation of American Scientists, 31 Oct. 2013, www.fas.org/blogs/fas/2013/10/avoiding-needless-wars-part-9-iraq/.

Bianculli, David. "Tom Wolfe: Writing Nonfiction 'Became A Great Game And A Great Experiment'." NPR, $\quad 15 \quad$ May 2018, www.npr.org/templates/transcript/transcript.php?storyId=611309448.

Boynton, Robert S. The New New Journalism: Conversations with America's Best Nonfiction Writers on Their Trade. Vintage Books, 2005.

Breslow, Jason M. "Colin Powell: U.N. Speech 'Was a Great Intelligence Failure." Public Broadcasting Service, 17 May 2016, www.pbs.org/wgbh/frontline/article/colin-powell-un-speech-was-a-great-intelligence-failure/.

Canada, Mark. Literature and Journalism in Antebellum America: Thoreau, Stowe, and Their Contemporaries Respond to the Rise of the Commercial Press. Palgrave Macmillan, 2011.

Chamonikolas, Krystof. Fictional Paths to "A Larger Truth" in American New Journalism. 2006. $\mathrm{PhD}$ dissertation. dspace.cuni.cz/bitstream/handle/20.500.11956/7425/DPTX_2007_2_11210_ASZK10001 128240_0_59601.pdf?sequence=1\&isAllowed $=\mathrm{y}$

Colebrook, Claire. Understanding Deleuze. Allen \& Unwin, 2002.

Deleuze, G., \& Guattari, F.. A thousand Plateaus: Capitalism and schizophrenia. Translated by B. Massumi, University of Minnesota Press, 1987.

---. Negotiations 1972-1990. Translated by M. Joughin. Columbia University Press. 1997.

Émigré. Iraqi Blog Count. Blogspot, www.iraqblogcount.blogspot.com/. Accessed 20 Dec. 2020.

Goc, Nicola. "Case Study 4: What's in a name? New journalism, literary journalism and creative nonfiction." Paperzz, 2008, pp. 279-287. www.paperzz.com/doc/8142302/case-study-4-what-s-in-a-name \%3F-new-journalism--literary

Grisham, C.J. "Veterans Are Not Above Reproach.” A Soldier's Perspective, asoldiersperspective.com/veterans-are-not-above-reproach/. Accessed 15 Mar. 2021.

Jenkins, H. et al. Confronting the challenges of participatory culture: Media education for the 21 st century. The MacArthur Foundation, 2006, www.macfound.org/media/article_pdfs/jenkins_white_paper.pdf

MacAskill, Ewen, and Julian Borger. "Iraq War Was Illegal and Breached UN Charter, Says Annan.” The Guardian, 16 Sept. 2004, www.theguardian.com/world/2004/sep/16/iraq.iraq

Martin, Brian. Backfire Manual: Tactics Against Injustice. Irene Publishing, 2012.

---“"Theory for activists.” Social Anarchism, no.44, 2010, pp. 22-41. www.bmartin.cc/pubs/10sa.pdf 
Massumi, Brian. Parables of the virtual: Movement, Affect, Sensation. Duke University Press, 2002

Mission Accomplished. Suzerainty, 14 March 2021, suzerainty.blogspot.com/.

Panzner, Michael. Financial Armageddon: Protecting Your Future from Four Impending Catastrophes. Kaplan, 2007.

Penrod, Diane. Using blogs to Enhance Literacy: the Next Powerful Step in 21st-Century Learning. Rowman \& Littlefield Education, 2007.

Physicians for Human Rights. "PHR Bulletin \#6: Iraq - Minefield and Cluster Bomb Target Site Information Must Be Made Available - Iraq." ReliefWeb, 6 May 2003, reliefweb.int/report/iraq/phr-bulletin-6-iraq-minefield-and-cluster-bomb-target-siteinformation-must-be-made.

Richelson, Jeffrey T. "Iraq and Weapons of Mass Destruction." The National Security Archive. $\begin{array}{lllll}\text { George } & \text { Washington } & \text { University, } & 20 & \text { Dec. }\end{array}$ www.nsarchive2.gwu.edu/NSAEBB/NSAEBB80/.

Ricketson, Matthew. Telling True Stories: Navigating the Challenges of Writing Narrative NonFiction. Allen and Unwin, 2015.

Riverbend. Baghdad Burning: Girl Blog From Iraq, Blogspot, 31 August 2003, riverbendblog.blogspot.com/2003/08/.

Rorty, Richard M. Contingency, Irony, and Solidarity. Cambridge U.P, 1999.

Schmidt, Thomas R. Rewriting the Newspaper: The Storytelling Movement in American Print Journalism. University of Missouri Press, 2019.

Scott, James C. Domination and the Arts of Resistance: Hidden Transcripts. Yale University Press, 1990.

Sharp, Gene. How Nonviolent Struggle Works. Albert Einstein Institution, 2013.

---. Politics of Nonviolent Action. Porter Sargent Publishers, 1980.

Skinner, Lukey. “Five Years Too Many, Olive Branch Optimism”, Blogspot, 19 Mar. 2008, 5:57, www.olivebranchoptimism.blogspot.com.

Stephenson, W. Gonzo Republic: Hunter S. Thompson's America. Continuum, 2012.

Striphas, Theodore G. The Late Age of Print: Everyday Book Culture from Consumerism to Control. Columbia University Press, 2011.

Thussu, Daya Kishan. "Live TV and Bloodless Deaths: War, Infotainment and 24/7 News." War and the Media: Reporting Conflict 24/7. Edited by Daya K. Thussu and Des Freedman, SAGE Publications Ltd, 2003, pp. 117-32. SAGE Knowledge, https://www.doi.org/10.4135/9781446215579.n9 
Parihar, Vipan K. "What Happens to Your Brain on the Way to Mars." Science Advances, vol. 1, no. 4, 2015, pp. 1-6. PubMed, https://doi.org/10.1038/scientificamerican0816-4.

"Iraq's Weapons of Mass Destruction: The Assessment of the British Government", FAS, September 2002, fas.org/nuke/guide/iraq/iraqdossier.pdf

Underwood, Doug. Literary Journalism in British and American Prose: An Historical Overview. McFarland \& Company, Inc., 2018.

Wallace, Lewis R. The View from Somewhere: Undoing the Myth of Journalistic Objectivity. University of Chicago Press, 2019.

Y1lmaz, Recep, et al. Handbook of Research on Transmedia Storytelling and Narrative Strategies. Information Science Reference, 2019. 